\title{
Efektivitas Partisi Air Buah Pare Terhadap Penurunan Gula Darah Diabetik Eksperimental Tikus Putih Jantan
}

\author{
(EFFECTIVENESS OF PARTITION WATER BITTER MELON AGAINST DECREASE IN \\ BLOOD SUGAR EXPERIMENTAL DIABETIC MALE RATS
}

\author{
Dwi Widananta Yogi Indra Yudha ${ }^{1}$, Nyoman Suartha ${ }^{2}$, Luh Made Sudimartini ${ }^{3 *}$ \\ ${ }^{1}$ Laboratorium Mikrobiologi Politeknik Kelautan Jembrana \\ ${ }^{2}$ Laboratorium Penyakit Dalam Veteriner \\ ${ }^{3}$ Laboratorium Farmasi Veteriner Fakultas Kedokteran Hewan Universitas Udayana \\ Jl. P.B. Sudirman Denpasar-Bali telp.0361-223791 *Email: md_sudimartini@unud.ac.id
}

\begin{abstract}
ABSTRAK
Penelitian ini bertujuan untuk mengetahui efektivitas partisi air buah pare terhadap penurunan gula darah diabetik eksperimental tikus putih jantan (Rattus norvegicus). Penelitian ini menggunakan dua puluh ekor tikus putih jantan berumur tiga bulan yang diadaptasikan selama 2 minggu. Tikus dikelompokkan menjadi empat kelompok yaitu kontrol negatif (P0); kontrol positif (P1), hanya diberikan streptozotocin; kelompok P2, diberikan streptozotocin dan ekstra pare $2 \% 200 \mathrm{mg} / \mathrm{kg} \mathrm{BB}$; kelompok P3 diberikan streptozotocin dan partisi air $50 \mathrm{mg} / \mathrm{kg}$ BB. Streptozotocin diberikian pada hari ke-0, ektrak pare dan partisi air diberikan mulai hari ke-3 sampai hari ke-20. Pengukuran kadar glukosa darah dilakukan pada hari ke $-1,0,4,11$ dan 18. Data yang diperoleh dianalisis menggunakan uji ANOVA one way. Hasil penelitian menunjukan bahwa partisi air buah pare pada dosis $50 \mathrm{mg} / \mathrm{kg}$ BB dapat menurunkan kadar glukosa darah secara nyata dibandingkan dengan kontrol positif.
\end{abstract}

Kata kunci: diabetik; eksperimental; ekstrak pare; partisi air; streptozotocin

\begin{abstract}
The aims of this research are to find out the effectiveness of water partition Momordicia charantia fruit to the decrease blood glucose of experimental diabetic male rats (Rattus norvegicus). This research used twenty 3 months old male rats which were adapted for 2 weeks. Rat grouped into 4 groups namely the negative control (P0), only given food and drink alone; positive controls (P1), was given only feed, drink, and streptozotocin; EP group (P2), was given food, drink, streptozotocin, and extra bitter melon 2\%; water partition group was given feed, drinking water and partitions streptozotocin $50 \mathrm{mg} / \mathrm{kg}$ body weight. Streptozotocin giving conducted on days 0, giving extract bitter melon and water partition conducted from day 3 to day 20. Measurement of glucose conducted on days $-1,0,4,11$ and 18. The obtained data were evaluated using one-way ANOVA test. The results showed that water partition Momordicia charantia fruit could decrease blood glucose levels in a dose of $50 \mathrm{mg} / \mathrm{kg}$ of body weight significantly compared with the positive control.
\end{abstract}

Keywords: experimental diabetes; bitter melon extract; water partition; streptozotocin.

\section{PENDAHULUAN}

Diabetes melitus (DM) merupakan salah satu masalah kesehatan yang berdampak pada produktivitas dan menurunkan mutu sumber daya manusia. Pada tahun 2000, jumlah penyandang DM di Indonesia sebanyak 8,4 juta jiwa dan diperkirakan akan mencapai angka 21,3 juta jiwa pada tahun 2030. Oleh karena itu Indonesia berada di peringkat keempat jumlah penderita DM terbanyak di dunia setelah India, China dan Amerika Serikat.
Namun, laporan untuk jumlah kasus diabetes melitus pada hewan belum ada. Diabetes mellitus merupakan penyakit metabolik yang berlangsung kronik di mana penderita diabetes tidak dapat memproduksi insulin karena sensitivitas terhadap reseptor insulin berkurang yang disebabkan adanya gangguan pada pankreas, sehingga terjadi kelebihan gula dalam darah (Sharma dan Kumar, 2011). Tubuh tidak dapat menghasilkan insulin juga dapat diakibatkan oleh rusaknya selsel $\beta$ pankreas (Alwan, 2010). 
Dabetes melitus dibedakan menjadi insulin dependent diabetes mellitus (IDDM) diakibatkan kekurangan hormon insulin dan non-insulin dependent diabetes mellitus (NIDDM) diakibatkan karena insulin tidak berfungsi dengan baik (Yuda et al., 2013). Gejala DM klasik berupa poliuria, polidipsia, polifagia, dan gejala lainnya seperti pruritus, polineurodegenerasi, penurunan berat badan dan penurunan tenaga. Bila penyakit berlanjut maka akan timbul gejala atau keluhan lain dari berbagai organ seperti dari ginjal, jantung, mata, impotensi dan sebagainya. Gejala ini merupakan komplikasi dan bukan gejala diabetes murni (Evacuasiany et al., 2005).

Keadaan DM dapat diinduksi dengan cara pemberian zat kimia aloksan dan streptozotozin (STZ) secara parenteral (Abeeleh et al., 2009; Lenzens, 2008). Strepzotosin bersifat diabetogonik karena merusak DNA dalam sel-sel B pankreas. Di samping itu, kerusakan DNA juga diduga akibat aktivitas senyawa nitrit oksida (NO). Strepzotosin adalah donor NO yang menyebabkan kerusakan sel pulau pankreas dengan cara meningkatkan aktivitas guanlin siklase (Elsner et al., 2000). Faktor lain yang mempengaruhi sensitivitas streptozotocin dalam menginduksi diabetes adalah strain dari tikus atau hewan percobaan yang digunakan (Abeeleh et al., 2009). Strepzotosin dapat digunakan untuk menginduksi DM tipe 1 dan tipe 2 yang diaplikasikan pada saat hewan percobaan masih pada tahap neonatal. Tikus yang diinjeksi dengan STZ pada saat neonatal setelah berumur 8-10 minggu, akan menunjukkan gejala hiperglikemia ringan dan hilangnya sensitivitas sel $\beta$ terhadap glukosa (Szkudelski, 2001).

Mengingat semakin tingginya jumlah penderita DM setiap tahun serta keterbatasan kemampuan masyarakat untuk melakukan pengobatan secara modern karena biaya untuk obat DM saat ini cukup mahal, maka perlu dikembangkan obat herbal yang efektif, murah, dan aman (Suartha et al., 2016). Dewasa ini penggunaan obat komplementer maupun alternatif semakin banyak menjadi pilihan penderita penyakit kronis maupun penyakit terminal yang menjalani penanganan paliatif dan membutuhkan biaya tinggi dalam penanganannya. Mahalnya harga obat modern dipasaran merupakan salah satu alasan untuk menggali kembali penggunaan obat tradisional. Obat alternatif kini telah banyak dikembangkan, obat tradisional dengan obat-obatan herbal telah terbukti memiliki efektifitas yang cukup baik. Obat tradisional merupakan salah satu warisan budaya bangsa yang perlu digali, diteliti, dan dikembangkan agar dapat dimanfaatkan secara maksimal untuk peningkatan pelayanan kesehatan (Dewi et al., 2014). Hal tersebut dibuktikan dengan peningkatan jumlah industri obat tradisional dan fitofarmaka, serta dukungan dari Pemerintah melalui Departemen Kesehatan, Republik Indonesia dalam mengupayakan perluasan penggunaan obat tradisional di Masyarakat (Fahri et al., 2005).

Tanaman yang telah dilaporkan berpotensi sebagai obat DM adalah buah naga (Dharmayuda, 2011), buah kersen (Muntingia calabura) (Pramono dan Santoso, 2014), buah tomat (Upritchard et al., 2000), buah pare (Momordica charantia) (Evacuasiany et al., 2005; Suartha et al., 2016). Peneliti Universitas Meiji di Jepang, melaporkan bahwa buah pare dapat dijadikan sebagai anti kanker. Buah pare tidak menimbulkan efek samping, tidak mempengaruhi pola makan dan berat badan (Bawa, 2009).

Buah pare memberikan andil yang besar untuk pengobatan tradisional, terutama di Indonesia. Tanaman ini sudah dibudidayakan di berbagai daerah di wilayah Nusantara. Pare tergolong tanaman semak semusim, yang hidupnya menjalar atau merambat dan permukaan kulit buah berbintil-bintil besar. Buah pare berbentuk bulat telur memanjang, warna hijau, kuning sampai jingga serta rasanya 
pahit Buah pare memiliki kandungan metabolit sekunder berupa saponin, flavonoid, polifenol, dan alkaloid. Senyawa-senyawa ini diduga dapat merangsang perbaikan sel-sel $\beta$ pankreas, sehingga dapat meningkatkan produksi insulin (Mulyanti et al., 2010; Suartha et al., 2016).

Pemurnian senyawa aktif dari ekstrak buah pare dapat dilakukan dengan partisi menggunakan larutan yang memiliki kepolaran yang berbeda. Partisi bertujuan untuk mengelompokkan metabolit yang terkandung dalam ekstrak kasar (ekstrak etanol) berdasarkan kepolarannya dan yang digunakan dalam penelitian ini adalah partisi air. Air adalah substansi kimia dengan rumus kimia $\mathrm{H}_{2} \mathrm{O}$ dan sering disebut sebagai pelarut universal karena air melarutkan banyak zat kimia.

Berdasarkan uraian di atas dilakukan penelitian untuk mengetahui efektivitas partisi air buah pare terhadap penurunan gula darah diabetik eksperimental tikus putih jantan.

\section{METODE PENELITIAN}

\section{Materi penelitian}

Objek yang digunakan dalam penelitian ini adalah 20 ekor tikus berumur 3 bulan dan berat badannya sekitar $150-$ 200 gram. Penelitian ini menggunakan ekstrak pare, etanol 70\%, betadine, streptozotosin, aquadest, n-heksan, etil asetat, klorofoam, dan air. Peralatan yang digunakan dalam penelitian ini yaitu: kandang pemeliharaan tikus, spuit $1 \mathrm{~mL}$, gelas ukur, gelas beker, mortal, kain kasa, kapas, neraca analitik, dan satu set GlukoDr® (GES GD-013), blender, penguap vacuum putar, oral sonde, aluminium foil, alat pemanas air, freeze dryer, pemanas air, masker, dan glove.

\section{Pembuatan ekstrak buah pare}

Ekstrak buah pare dibuat dengan cara menimbang sebanyak $5 \mathrm{~kg}$ buah pare gajih segar, kemudian dihancurkan dengan menggunakan blender, ditambahkan pelarut etanol $70 \%$, dimasukan ke dalam wadah, ditutup dan dibiarkan selama dua hari terlindung dari cahaya sambil diaduk. Setelah itu disaring sehingga didapat maserat. Ampas dimaserasi dengan etanol $70 \%$ menggunakan prosedur yang sama, maserasi dilakukan sampai diperoleh maserat yang jernih. Semua maserat etanol digabungkan dan diuapkan dengan menggunakan alat penguap vakum putar pada temperature $\pm 40^{\circ} \mathrm{C}$ sampai diperoleh ekstrak etanol kental kemudian dikeringkan menggunakan freeze dryer.

Partisi air bertujuan untuk mengelompokkan metabolit yang terkandung dalam ekstrak kasar berdasarkan kepolarannya. Partisi yang digunakan diurutkan dinilai berdasarkan tingkat kepolaranya dari non-polar hingga polar. Untuk hal itu digunakan pelarut air yang kepolarannya berbeda, yaitu: $n-$ heksan, kloroform, dan etilasetat dengan cara sebagai berikut. Pemisahan ekstrak pada tahap ini dilakukan dengan cara ekstrak kasar dilarutkan dalam $100 \mathrm{~mL}$ campuran etanol-air (3:7), kemudian etanolnya dievaporasi sampai semua etanol menguap. Selanjutnya dipartisi dengan n-heksan (5 x $50 \mathrm{~mL}$ ). Partisi nheksan $(\mathrm{EH})$ dikumpulkan dan residunya (ekstrak air) dipartisi kembali dengan kloroform $(5 \times 50 \mathrm{~mL})$ kemudian partisi kloroform (EK) dikumpulkan. Selanjutnya dengan langkah yang sama partisi air dipartisi kembali dengan etilasetat (5 x 50 $\mathrm{mL}$ ). Setelah itu diperoleh residunya (partisi air).

\section{Partisi air 2\%}

Partisi air ditimbang sebanyak 2 gram kemudian dilarutkan dengan aquadest sampai mencapai volume $100 \mathrm{~mL}$ dan dihomogenkan untuk mendapatkan larutan partisi air $2 \%$.

\section{Persiapan hewan coba}

Hewan yang digunakan dalam penelitian ini adalah 20 ekor tikus putih (Rattus norvegicus) jantan yang berumur 3 bulan. Tikus terlebih dahulu dipelihara selama 2 minggu dalam kandang untuk adaptasi kondisi lingkungan . Semua tikus 
ditimbang berat badannya dan disuntik dengan STZ dengan dosis $40 \mathrm{mg} / \mathrm{kg}$ BB secara intraperitoneal kecuali tikus kontrol negatif (-). Tikus dibagi menjadi 4 perlakuan, yaitu P0: Kontrol negatif (tanpa diberikan ekstrak), P1: Kontrol positif (STZ), P2: STZ + ekstrak pare 2\% 200 $\mathrm{mg} / \mathrm{kg} \mathrm{BB}$, dan P3: STZ + partisi air buah pare $50 \mathrm{mg} / \mathrm{kg} \mathrm{BB}$, masing masing diberikan pada lima ekor tikus yang ditempatkan dalam kandang terpisah. Pakan yang diberikan adalah konsentrat dan air minum ad-libitum. Sebelum diberikan perlakuan, tikus dipuasakan terlebih dahulu selama 24 jam (Aybar et al., 2001). Pemberian perlakuan ekstrak pare $2 \%$ dan partisi air diberikan pada hari ke-3 setelah penyuntikkan STZ sampai hari ke-20.

\section{Pemeriksaan kadar glukosa darah}

Prinsip pengukuran kadar glukosa darah menggunakan metode enzimatik, menggunakan alat Gluko-Dr ${ }^{\circledR}$ (merk GES GD-013) yang bereaksi secara spesifik dengan glukosa yang terdapat di dalam darah. Molekul glukosa yang dioksidasi oleh enzim Glucose Oxidase (GOD) menghasilkan elektron yang ditangkap oleh elektroda sehingga kadar glukosa berbanding lurus dengan sinyal elektronik yang diterima. Jumlah darah yang dibutuhkan untuk mengukur kadar glukosa darah adalah 2,5-4 $\mu$ L. Darah diletakan pada sisi kanan test strip, darah akan terserap secara otomatis dan hasil pengukuran terbaca setelah 11 detik pada Gluko-Dr® test meter. Kadar glukosa darah diukur dalam satuan $\mathrm{mg} / \mathrm{dL}$. Pengukuran kadar glukosa darah dilakukan pada hari ke $-1,0,4,11$, dan 18 setelah penyuntikkan STZ.

\section{Analisis data}

Rancangan penelitian yang digunakan adalah rancangan acak lengkap (RAL). Data kadar glukosa darah yang diperoleh dianalisis dengan ANOVA (Analysis Of Variance) One Way. Untuk mengetahui perbedaan antar perlakuan digunakan uji Duncan (Stell dan Torrie, 1980).
Perhitungan statistik dilakukan dengan bantuan piranti SPSS 16.0 for Window.

\section{HASIL DAN PEMBAHASAN}

Hasil

Perlakuan P1, P2, dan P3 mengakibatkan tikus mengalami DM tipe 2 karena zat reactive oxygen spesies (ROS) yang menghambat reseptor insulin (Nugroho, 2006; Abeeleh et al., 2009). Hasil pemeriksaan kadar glukosa darah tikus putih ( $R$. norvegicus) hiperglikemia pada hari ke-18 yang diberikan partisi air buah pare ( $M$. charantia) disajikan pada Tabel 1. Pada hari ke-0 perbedaan yang nyata $(\mathrm{P}<0.05)$ terjadi pada kelompok perlakuan P1, P2 dan P3 dengan kelompok perlakuan P0. Pada hari ke-4 kelompok perlakuan $\mathrm{P} 0$ dan $\mathrm{P} 2$ berbeda nyata dengan kelompok P1 dan P3. Pada hari ke-11 dan 18 didapatkan hasil P0, P2, P3 berbeda nyata dengan P1. Grafik kadar glukosa darah tikus putih pada hari ke-1 sampai hari ke-18 dapat dilihat pada Gambar 1 .

Strepzotosin meningkatkan kadar glukosa darah dengan gejala-gejala diabetes, seperti hiperglikemia, hipoinsulinemia, polifagia, poliuria dan polidipsi yang disertai dengan penurunan berat badan tampak dalam waktul minggu hingga 10hari, maka hal ini mengindikasikan kerusakan dari pulau langerhans pankreas yang bersifat irreversible (Akbarzadeh et al., 2007).

Keadaan hiperglikemik ditandai dengan adanya peningkatan kadar glukosa darah di atas normal. Tikus kelompok P0 pada hari ke -1 sampai hari ke-18 kadar glukosanya normal. Tikus kelompok P1 pada hari ke -1 masih dalam keadaan normal, namun pada hari ke-0 sampai dengan hari ke-11 terjadi peningkatan kadar glukosa darah (kondisi hiperglikemik) dan pada hari ke-18 terjadi penurunan kadar glukosa darah walaupun masih dalam kondisi hiperglikemia berat. Tikus kelompok P2 pada hari ke -1 sampai hari ke-18 kadar glukosa darahnya masih dalam keadaan normal namun bersifat fluktuatif. Tikus kelompok P3 pada hari ke 
-1 menunjukan kadar glukosa normal, namun pada hari ke-0 sampai hari ke-4 terjadi peningkatan glukosa sehingga tikus
DOI: 10.24843/bulvet.2018.v10.i01.p02

mengalami hiperglikemik berat lalu pada hari ke-11 sampai hari ke-18 terjadi penurunan kadar glukosa darah.

Tabel 1. Rata- rata kadar glukosa darah pada tikus putih ( R.norvegicus) hiperglikemia yang diberikan partisi air buah pare (M.charantia)

Rata-rata kadar glukosa darah tikus putih jantan (mg/dl) pada hari ke-

\begin{tabular}{cccccc}
\hline Perlakuan & -1 & 0 & 4 & 11 & 18 \\
\hline P0 & $104,7 \pm 8,11^{\text {ab }}$ & $105,2 \pm 4,32^{\mathrm{a}}$ & $103,4 \pm 6,23^{\mathrm{a}}$ & $112,2 \pm 21,45^{\mathrm{a}}$ & $104,4 \pm 19,32^{\mathrm{a}}$ \\
P1 & $112,3 \pm 6,88^{\mathrm{b}}$ & $335,00 \pm 104,12^{\mathrm{b}}$ & $235 \pm 37,32^{\mathrm{b}}$ & $395,6 \pm 88,82^{\mathrm{b}}$ & $387,8 \pm 58,8^{\mathrm{b}}$ \\
P2 & $98,6 \pm 12,16^{\mathrm{a}}$ & $322,2 \pm 103,77^{\mathrm{b}}$ & $113,4 \pm 11,33^{\mathrm{a}}$ & $123,3 \pm 4,35^{\mathrm{a}}$ & $98,5 \pm 15,34^{\mathrm{a}}$ \\
P3 & $110,2 \pm 5,215^{\mathrm{b}}$ & $396 \pm 114,715^{\mathrm{b}}$ & $538,8 \pm 136,842^{\mathrm{c}}$ & $189,2 \pm 113,834^{\mathrm{a}}$ & $134,8 \pm 98,799^{\mathrm{a}}$ \\
\hline
\end{tabular}

Keterangan: Angka yang diikuti huruf superscript yang sama ke arah kolom tidak berbeda nyata $(\mathrm{P}>0,05)$. Sedangkan angka dengan huruf yang berbeda pada kolom yang sama menunjukkan nilai yang berbeda nyata $(\mathrm{P}<0,05)$.

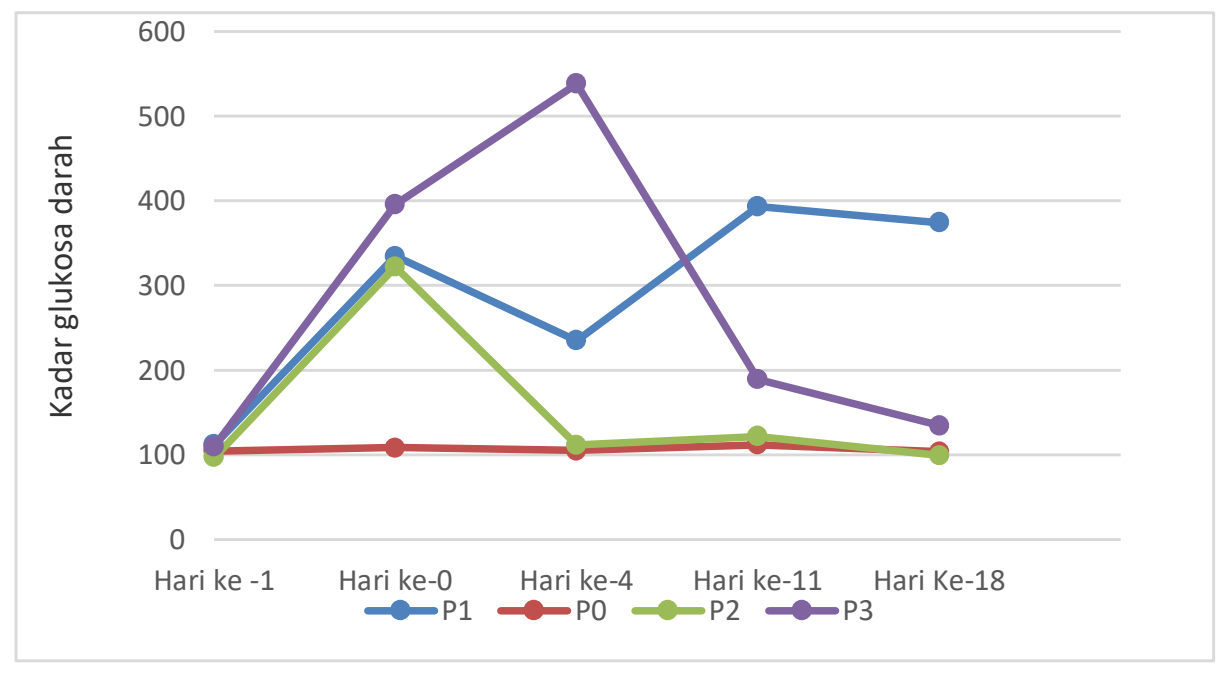

Gambar 1. Grafik Kadar Glukosa darah tikus putih pada hari ke -1 sampai hari ke-18

\section{Pembahasan}

Pada harike-1 kadar glukosa darah tikus kelompok P0, P1, P2 dan P3 masih dalam batas normal. Ini disebabkan karena STZ akan mulai bekerja dalam waktu 2 sampai 3 hari (Suharmiati, 2003). Pada hari ke-0 tikus kelompok P1, P2, dan P3 mengalami peningkatan kadar glukosa. Ini dikarenakan STZ bekerja dengan membentuk radikal bebas sangat reaktif yang dapat menimbulkan kerusakan pada membran sel, protein dan deoxyribonucleic acid (DNA), sehingga menimbulkan gangguan produksi insulin oleh sel-sel beta pulau langerhans pada pankreas (Erwin et al., 2013).

Erwin et al. (2013) mengatakan bahwa, sebagai salah satu kelenjar endokrin, pankreas bertanggung jawab dalam mengatur kadar glukosa darah. Perubahan kadar glukosa dalam plasma mengakibatkan penyesuaian sekresi insulin untuk mengembalikan kadar glukosa darah pada rentang yang normal.

Insulin adalah hormon alami yang dihasilkan oleh pankreas dan berfungsi untuk mengubah dan menggunakan glukosa darah untuk membuat energi yang nantinya digunakan untuk menjalankan 
fungsinya. Berkurangnya insulin akan memicu terjadinya hiperglikemia, dan glukosa dalam darah tidak dapat diubah menjadi energi oleh sel dan memicu proses glukogenesis (Suarsana et al., 2006).

Pemberian ektrak buah pare pada tikus putih hiperglikemia memiliki banyak mekanisme baik, yaitu 1) pencegahan penyerapan glukosa dalam saluran pencernaan, 2) meningkatkan penyerapan glukosa dalam jaringan, 3) meningkatkan metabolisme glukosa, 4) meningkatkan insulin dengan menstimulasi sel beta pankreas. Hal ini dikarenakan ekstrak buah pare mengandung senyawa aktif karantin, vicine dan polypeptide $-P$ insulin. Beberapa penulis melaporkan bahwa ektrak buah pare meningkatkan penyerapan glukosa dalam sel, sehingga meningkatkan metabolisme glukosa (Alam, 2015).

Pada hari ke-4 sampai hari ke-18 kadar glukosa tikus kelompok P3 mengalami penurunan. Efek partisi air terlihat setelah hari ke-4, namun penurunan kadar glukosa terlihat jelas dari hari ke-11 dengan ratarata $189,2 \pm 113,84$ dibandingkan hari ke4 dengan rata- rata $538,8 \pm 136,847$. Pada hari-18 terjadi penurunan kadar glukosa pada tikus kelompok P3 dengan rata- rata $134,8 \pm 98,799$.

Penggunaan partisi air buah pare mampu menurunkan kadar glukosa darah tikus setelah hari ke-4, lebih lambat dibandingkan pemberian ektrak etanol buah pare. Hal ini disebabkan kandungan kimia pada ekstrak etanol masih utuh dan dosis yang diberikan lebih tinggi dibandingkan partisi air. Ekstrak buah pare dilaporkan meningkatkan penyerapan glukosa dan diregulasi GLUT-4, PPAR-y dan phosphatidylinositol-3 kinase (PI3K) di L6 Myotubes (Alam et al., 2015).

Kandungan buah pare yang berguna dalam penurunan gula darah adalah charantin, momorsidin dan polyeptide- $P$ insulin (polipeptida yang mirip insulin) yang memiliki komponen yang menyerupai sulfonylurea (obat antidiabetes paling tua dan banyak dipakai).
Mekanisme kerja dari charantin adalah menstimulasi sel beta kelenjar pancreas untuk memproduksi insulin lebih banyak, dan meningkatkan cadangan glikogen di hati. Sedangkan polyeptide- $P$ insulin menurunkan kadar glukosa darah secara langsung (Pratama, 2011).

\section{SIMPULAN DAN SARAN}

\section{Simpulan}

Partisi air buah pare (Momordicia charantia) dengan dosis $50 \mathrm{mg} / \mathrm{kg}$ bb efektif menurunkan kadar glukosa darah tikus putih jantan (Rattus norvegicus).

\section{Saran}

Perlu dilakukan penelitian lebih lanjut untuk mengetahui efek pemberian partisi air buah pare (Momordicia charantia) terhadap diabetik eksperimental tikus putih jantan (Rattus novergicus) dengan pemberian induksi zat diabetagon yang lain dan pengaruhnya terhadap gambaran histopatologi sel $\beta$ pulau langerhans dalam kelenjar pankreas.

\section{UCAPAN TERIMAKASIH}

Penulis mengucapkan terima kasih kepada Direktorat Penelitian dan Pengabdian kepada Masyarakat, Direktorat Jendral Pendidikan dan Kebudayaan Republik Indonesia atas bantuan dana penelitian, melalui Lembaga Penelitian dan Pengabdian Masyarakat Universitas Udayana (LPPM UNUD), dengan kontrak No: 104.18/UN 14.2/PNL.01.03.00/2014.

\section{DAFTAR PUSTAKA}

Abeeleh MA, Ismail ZB, Alzaben KR, Abu-Halaweh SA, Al-Essa MK, Abuabeeleh J. 2009. Induction of diabetic mellitus in rats using intraperitoneal streptozotocin: A comparison between two strains of rats. European J Sci Res 32(3): 398402.

Akbarzadeh A, Norouzian D, Mehrabi MR, Jamshidi SH, Farhangi A, Allah VA, Mofidian SMA. 2007. Induction of Diabetes by Streptozotocin in Rats. Indian J Clin Biochem 22(2): 60-64. 
Alam MA. 2015. Benificial Role of Bitter Melon Supplementasion in obesity and Related Complication in Metabolic syndrome. J Lipids 2015:1-18.

Alwan A. 2010. Raising the priority accorded to diabetes in global health and development. Int $J$ Diabetes Melitus 2(3): 139-140.

Bawa IGAD. 2009. Isolasi Dan Identifikasi Golongan Senyawa Toksik Dari Daging Buah Pare (Momordica charantia L.). J Kimia 3(2): 117-124.

Dewi YS, Anthara MS, Dharmayudha AAGO. 2014. Efektifitas Ekstrak Daun Sirih Merah (Piper crocatum) Terhadap Penurunan Kadar Glukosa Darah Tikus Putih Jantan (Rattus novergicus) Yang Di Induksi Aloksan. Bul Vet Udayana 6(1): 74-75.

Dharmayuda AAGO. 2011. Identifikasi Golongan Senyawa Kimia dan Pengaruh Ekstrak Etanol Buah Naga Daging Putih (Hylocereus undatus) Terhadap Penurunan Kadar Glukosa Darah Serta Berat Badan Tikus Putih Jantan (Ratus novergicus) yang Diinduksi Aloksan. Tesis. Denpasar. Universitas Udayana.

Dharmayudha AAGO, Anthara MS, Wiranata IMA, Sudimartini LM. 2014. Efektifitas Ekstrak Daun Sirih Merah (Piper crocatum) Terhadap Peningkatan Berat Badan Tikus Putih (Rattus novergicus) Jantan Kondisi Diabetes Yang Di Induksi Aloksan. Bul Vet Udayana 6(2): 175-178.

Elsner M, Guldbakke B, Tiedge M, Munday R, Lenzen S. 2000. Relative Importance of Transport and Alkylation for pancreatic beta-cell toxicity of STZ. Diabetologia 43(12): 1528-1533.

Erwin, Etriwati, Muttaqien, Pangestiningsih TW, Widyarini S. 2013. Eksresi Insulin pada Pankreas Mencit (Mus Musculus) yang diinduksi dengan streptozotocin Berulang. $J$ Kedokteran Hewan 7(2): 97-100.

Evacuasiany E, Darsono L, Rosnaeni. 2005. Studi Efektivitas Antidiabetik
Ekstrak Air dan Ekstrak Etanol Buah Pare (Momordica Charantia Linn) pada Mencit Diabet Aloksan. J Kedokteran Maranatha 4(2): 1-13

Fahri C, Sutarno, Listiawati S. 2005. Kadar Glukosa dan Kolesterol Total Darah Tikus Putih (Ratttus norvegicus L) Hiperglikemik setelah Pemberian Esktrak Metanol Akar Menirfan (Phyllanthus niruri L.). Biofarmasi 3(1): 1-6.

Lenzens S. 2008. The Mechanisme Of Aloksan and Streptozotocin Induced Diabetes. Diabetelogi 51(2): 216-226.

Mulyanti S, Musthapa I, Aisyah S. 2010. Isolasi dan Karakteristik Senyawa Metabolit Sekunder Dari Fraksi Aktif Anti Diabetes Buah Pare. J Tekhnol Kimia 1(2): 191-199.

Nugroho AE. 2006. Review Hewan Percobaan Diabetes Mellitus: Patologi Dan Mekanisme Aksi Diabetogenik. Biodivesrsitas 7(4): 378-382.

Pramono VJ, Santoso R. 2014. Pengaruh Ekstrak Buah Kersen (Muntingia calabura) Terhadap Kadar Gula Darah Tikus Putih (Rattus novergicus) yang Diinduksi Streptozotocin (STZ). J Sain Vet 32(2): 218-223.

Pratama FT. 2011. Pengaruh decocta buah pare (Momordica charantia L.) Terhadap penurunan kadar glukosa darah tikus wistar yang diberi beban glukosa. Tesis. Fakultas Kedokteran, Universitas Diponegoro.

Sharma US, Kumar A. 2011. Antidiabetic Effect of Rubus ellipticus Fruit Extracts in Alloxan Induced Diabetic Rats. J Diabetology 2(4): 16.

Suarsana, N. Prioseoeryanto, B. P., Wresdiati, T., dan Bintang, M. 2006. Sintesa glikogen hati dan otot tikus diabetic yang diberi ektrak tempe. $J$ Vet 11(3): 190-195.

Suartha IN, Swantara IMD, Rita WS. 2016. Ekstrak Etanol dan Fraksi Heksan Buah Pare (Momordica charantia) Sebagai Penurun Kadar 
Glukosa Darah Tikus Diabetes. $J$ Vet 17(1): 30-36.

Suharmiati. 2003. Pengujian Bioaktivitas Anti Diabetes Mellitus Tumbuhan Obat. Badan Penelitian Pengembangan dan Kesehatan. Pusat Penelitian dan Pengembangan Pelayanan dan Teknologi Kesehatan. Departemen Kesehatan RI. Surabaya.

Szkudelski T. 2001. The Mecanism of Alloxan and Streptozotocin Action in Beta Cell of The Rat Pancreas. Physiol 50(6): 536-546.

Upritchard JE, Sutherland WHF, Mann JI. 2000. Effect of supplementation with tomato juice, vitamin $\mathrm{E}$, and vitamin $\mathrm{C}$ on LDL oxidation and products of inflammatory activity in Type 2 diabetes. Diabetes Care 23(6): 733738.

Yuda IKA, Anthara MS, Dharmayudha AAGO. 2013. Identifikasi Golongan Senyawa Kimia Estrak Etanol Buah Pare (Momordica charantia) dan Pengaruhnya Terhadap Penurunan Kadar Glukosa Darah Tikus Putih Jantan (Rattus novergicus) yang Diinduksi Aloksan. Bul Vet Udayana 5(2): 87-92. 